繊維素の含有する水分が完全に除去されたとすると, 原試料の吸 濕度を $5 \%$ とする時は $16.6 \mathrm{cc}$ の無水醋酸で充分である管である。 上の䔰驗では 25cc で充分で兾際上三醋酸裁維素が出來たのであ るが 20cc では最早幾分不足であつた。また $15 \mathrm{cc}$ 及 $10 \mathrm{cc}$ の例 を見るも無水醋酸が完全に纎維素の醋酸化に消費されたとしては 醋酸含有率は低くすぎる。此事富に關して2 個の解䆁が可能であ る。其 1 は醋酸瀻維素々無水醋酸の間に topochemisch なエス テル化平衡の成立した事, 其 2 は此處に行つた前處理にも拘は
らず水分の除去が不完全でそれに依り無水醋酸が消費された事で ある。此兩者いづれであるかと云ふ事は割に容易に賏驗的に決定 出來る事であり目下兾驗中である。もし第1 の解釋に相當する事 富が成立して居るものであれば，是に依り第 1 次繊維狀アセトン 可溶性醋酸繊維素が出來る筈である。

本研究に當り㭪助を與へられた谷口工業獎欮會に感謝の意を表 する。

（京都帝國大學工舉部工業化學教室·理化學研究所喜多研究室）（昭和 13 年 1 月 20 日受理）

\title{
（44）第1 次アセトン及クロロフォルム可溶性醋酸繊維素の製成
}

\author{
谷 口: 政 勝 - 櫻 田 一 郎
}

前に著者等の述ざ醋酸織維素の溶解譏檴に關する見解(本誌, 昭和 12, 40, 224）飞基 き，普通工業的に用ひられる醋没化浴 に依り直接にアセトン可溶性醋酸瀻維素を製成することに成功し たので，其製造方法並びに製品の溶解機棒に對する檢討考察綿果

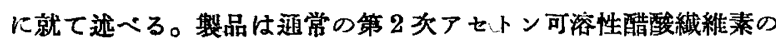
溶劑たるアセトン，醋酸メチル等に可溶性であるのみならずク口

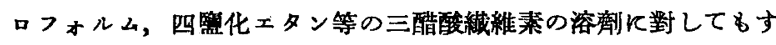
へて可溶性である。

\section{緒言}

現在工業的に廣い使途を有するアセトン可溶性醋酸繊維素は纎 維素を醋酸化して一旦三醋酸繊維素とした後これを部分鹼化して 製つて居る。か」る二次的な製造工程を經ずして直接瀻維素の醋 酸化に依りアセトン可溶性のものが出來れば色々の點に於て有利 なことは云ふまでもない。特許交䵉上には從來展々この試みが見 出され，例へば階段的醋酸化に依る方法 (Wagner, D. R. P., 299,181; Zdanowich, Brit. P., 139,232: 505,608), 無水醌酸蒸氣に 依り纎維狀態で醌酸化を行ふ方法 (Soc. Chim. Usines Rhône, D. R. P., 258,879; Brit. P., 25,893)，接觸劑 として酸性硫酸盖 を用ふる方法 (Soc. Oyonnithe, Franz. P., 427,265; Bayer Farbenfabrik, Franz. P., 417,274) 等がある。所がかつる方法で '製られた醋酸瀻維素には往々不安定な膠質化學的性質が認められ (Yarsley, Zelluloseazetate, Berlin, 1927), 今の所工業的に價値 のあるアセトン可溶性醋酸繊維素は一次的工程に依つて製造出來 ないとされて居る。然らば何故一次的工程に依つて製造出來ない かと云ふに，普通の工業的醋酸化の方法ではどうしても醋酸化反 應が不均一に起り一部分は三醋酸瀻維素にまで進んで居る一方一 部分は未だ二醋酸繊維素或は一醋酸瀻維素附近に止まると云ふ如 き狀態になるからであると考へられる。

所が著者等は前に纎維素誘導體の如き高分子物質に關し其溶解 機㩐に對する一考察を試み次の如き現象を考へこれを或程度赛驗 的にも確め得た（㣗口·櫻田, 本誌, 昭和 $12,40,224$ )。郎ち或 液體に可溶性及非溶性の 2 種の高分子物質がある時, 非溶性物 質中に可溶性物質を適當に混合せしめると其混合物は可溶性にな る。但しこの場合兩物質の化學的組成は著しく異ならないことを
必要とし, 且其混合狀態は膠質粒子的均一にあることが䋓對に必 要である。か」る混合物をつくるには一旦兩物質を共通な溶劑中 に溶解し, 即ち兩物質を溶解狀態で混合し後之を急激に沈測或は フィルムとして再生するのである。著者等は其㟬驗例の一として 三醋酸瀻維素とアセトン可溶性第 2 次醋酸纎維素とを適當に混合 してクロロフォルム及アセトンに可溶性の醋酸瀻維素をつくつ た，郎ち互ひに醋酸含有率を異にし從つて溶解性を著しく異にす る醌酸繊維素でもこれを適當な方法で混合再生させてやれば, 兩 醋酸盞維素の各溶劑に夫々可溶性のものが得られるのである。所 が普通の醋酸, 無水醋酸, 硫酸浴に依り醋酸化を行つた場合反鹰 が完結する少し前, 浴中に生成した醋酸瀻維素は簡單に考へて三

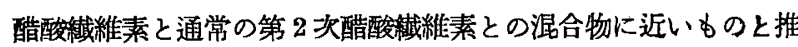
察される。もし然らば, 別に特殊な万法を用ひずとも普通の酷酸, 無水醋酸, 硫酸浴を用ひて醋酸化を行ひ, 反應が大體九分通り終 つた所で浴液は適當に沈澱處理さへすれば上述の原理に依りアセ トンにもクロロフォルムにも可溶性な醋酸纎維素が得られはしな いかと考へられる。

か」る考への下に著者等は繊維素を普通の醋酸，無水醋酸，硫 酸浴で醋酸化し反應が $90 \%$ 餘り進んだ所で反鹰を停止し浴液を 適當な方法で沈澱してアセトン及クロロフォルムに可溶性の醋酸 織維素を製ららと試みたのである。

\section{實驗結果及考察}

\section{（1）第 1 次アセトン及クロロフォルム 可溶性醋酸緎維素の製成實驗}

繊維素試料としてはチッシュ紙，濾紙，ソルカパルプ $\alpha \mathrm{NN}$ 等 を使用し, 浴の組成は $10 \mathrm{~g}$ の纎維素試料に對し無水醌酸 $40 \mathrm{cc}$, 醋酸 $40 \mathrm{cc}$, 硫酸 $1 \mathrm{~g}$ の普通の醌酸化浴を硫酸量を種々變更して用 ひた。次に沈澱方法であるが，これは浴液を醋酸或はアセトンで 3〜5 倍に稀釋し薄愿として常溫のドラフト中で乾燥しフィルム とした。かくして實驗を行つた所何れの場合に於ても醌酸含有率 が大體 $59 \%$ 內外の所でアセトン及クロロフォルム可溶性の醋酸 繊維素が得られたのである。

第 1 表は其一例を示したもので浴の組成が無水醋酸 $40 \mathrm{cc}$, 醋 酸 $40 \mathrm{cc}$, 硫酸 $1 \mathrm{~g}$ の賽踰例である, 郎ち醋酸 化の各反應時間每 
に一定量の浴液をとり，これを上述の如くフィルムとして乾燥し 洗临, 安定化した後よく乾燥して其れのアセトン及クロロフォル ムに對する溶解度並びに醋酸價を測定したのである。尚比較のた め各時間每に同じ浴液を通常の如くそのまま水中に注入沈澱せし め後洗策, 安定化, 乾燥した試料に關しても同樣の溶解度を測定 した。份赛驗溫度は最䘞浴の溫度を $10^{\circ} \mathrm{C}$ に保ち繊維素試料が浴 液中に充分浸漬した後徐々に溫度を高めて $25^{\circ} \mathrm{C}$ とし後この溫度 の下に醋酸化を續けた。佾繊維素試料 としてはチッシュ紙を用 ひた。

$$
\text { 第 } 1 \text { 表 }
$$

無水醋酸, 醋酸, 硫酸浴 (40cc: 40cc: $1 \mathrm{~g}$ ) 飞依 ろチッシュ紙 $(10 \mathrm{~g})$ の各時閒每に於ける醋酸化生 战物のアセトン及クロロフォルムに對する溶解度

$$
\text { 宽 驗 溫度 } 25^{\circ} \mathrm{C}
$$

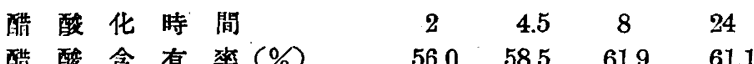

\section{生成物の溶解度 $(\%)$}

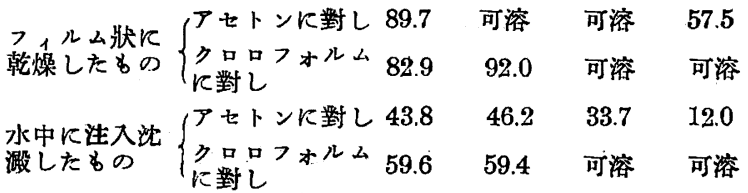

第 1 圖 各醋酸化時問に於ける生成酷酸䄉維 素のアセトンへの溶解度

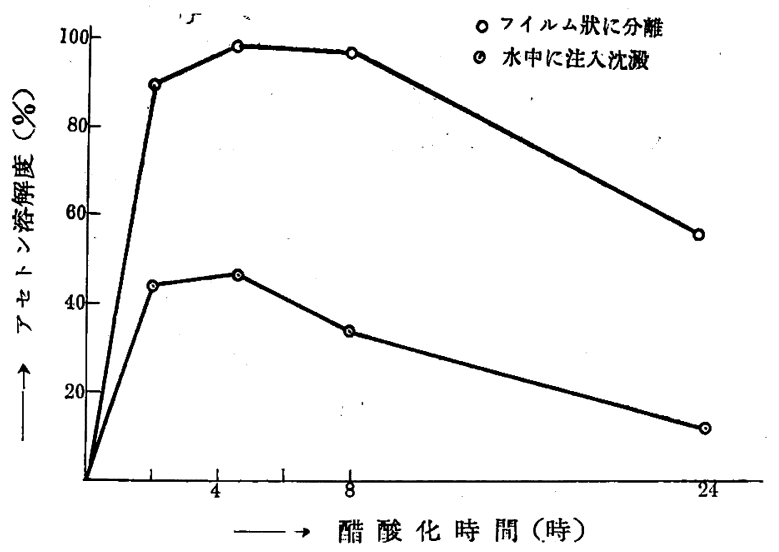

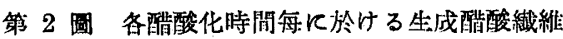
秦のクロロフォルムへの溶解度

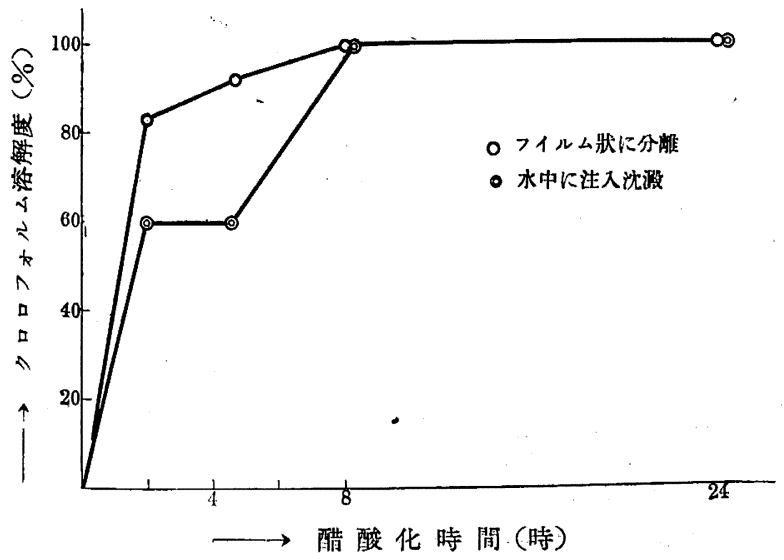

第 1 表の結果を判り易く圆示すると第 1 圖及第 2 圖の如くで ある。即ち通常の如くして繊維素を醋酸化する場合，浴液をその まっ水中に注加して沈澱をつくると得られた生成物は常にアセ卜 ンに餘り溶解しない，例へば上の例を見るに醋酸化時間が 4.5 時 間醋酸含有棃が $58.5 \%$ に達した時に漸く $46.2 \%$ の最高の溶解度 を示すに過ぎない，これに對し，浴液を稀釋しフィルム狀に乾燥 してつくつた生成物は醌酸化時間 4.5 時間, 醋酸價 $58.5 \%$ の點 で既に透明可溶となる。尤も醋酸化が充分進み例へば 24 時間後 では生成物全體が三醌酸繊維素になつてるると考へられるのでこ の時はもはや溶解度は減少し $57.5 \%$ となる。又クロロフォルム に對する溶解度は云ふまでもなく醋酸化の進むにつれて堛大する が，フィルム狀に乾燥してつくつた試料の方が常により高い溶解 度を示し醋酸價 $58.5 \%$ の點で既に殆ど可溶となり $92.0 \%$ の溶解 度を示す。

かくの如くして通常の醋酸化浴に依り簡單にアセトン及クロロ フォルム可溶性の醋酸繊維素が第 1 次的に得られた。向この彆品 はアセトン及クロロフォルムに可溶なるのみならず, 三醌酸繊維 素及第 2 次酷酸繊維素夫々の溶劑に共通に可溶である。郎ち醋酸

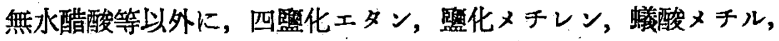
醋酸メチル等に唀明可溶である。又部分的溶劑例へば醋酸エチル にはセリットが $24 \%$ の溶解度を示すに對し， $59.2 \%$ の溶解度を 示す。

次に醋酸化浴の硫酸の濃度を種々變へて同樣の實驗を行つた。 この場合は醋酸化の反應をより均一円滑に進めるため预じめ チッシュ紙を氷醋酸で 30 分間者沸し後 1 畵夜浸清したりのを压 捾して醋酸を可及的除いて使用した。其結果は第 2 表に示す。但 し生成醋酸繊維素はすべて前述の如く溶液をアセトンで稀釋して フィルム狀に乾燥したりので, 溶解度はアセトンに對してのみ定 量を行つた。

\section{第 2 表}

種々の硫酸橴度の無水醋酸, 醋酸, 硫酸浴飞依了第 1 次 アセトン及クロロフォルム可溶性醋酸織維素製造偊驗 解驗温度 $25^{\circ} \mathrm{C}$

試料 醋酸浸漬能處理を行へろチッシニ紙

A）醌酸化浴 無水醋酸 $40 \mathrm{cc}:$ 酛酸 $40 \mathrm{cc}$ ：硫酸 $1 \mathrm{~g}$

\begin{tabular}{|c|c|c|c|}
\hline 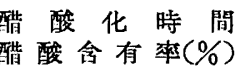 & $\begin{array}{c}2 \\
58.9\end{array}$ & $\begin{array}{r}4.5 \\
59.3\end{array}$ & $\begin{array}{c}6 \\
59.0\end{array}$ \\
\hline セトンに對する溶 & 96.2 & 可 & 可 \\
\hline
\end{tabular}
(但し $10 \mathrm{~g}$ の繊維素儿對し)

B）醌酸化浴 無水醌酸 $40 \mathrm{cc}:$ 醌酸 $40 \mathrm{cc}$ : 硫酸 $2 \mathrm{~g}$

$$
\text { 醋 酸 化 時 閣 } 5
$$$$
\text { アセトンイ對する溶解度可 溶 }
$$

C) 醈酸化浴 無水酛酸 $40 \mathrm{cc}$ : 醋酸 $40 \mathrm{cc}$ : 硫酸 $5 \mathrm{~g}$

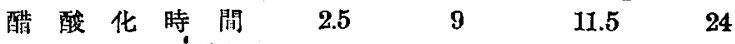
$\begin{array}{lllll}\text { 醋酸合有犁 }{ }^{\prime}(\%) & 52.1 & 58.3 & - & 61.6\end{array}$ アセトンに對する溶 一部不溶 可溶 可 溶 一部可溶

第々表 (A)は第 1 表の場合と實驗條件は同じで,た だ試料のチ。 シュ紙が第 1 表の場合は風乾のま〉のものであつたのが第 2 表 では预じめ醋酸浸漬處理を行つて居る。兩表を比較すれば判る如 く, 繊維素試料を㜈じめ醋酸浸漬處理しておくと反應がより迅速 円骬に進み，醋酸化 2 時間で既に殆どアセトンに可溶となる。浴 の硫酸濃度を次第に增大しても本質的に大した差違は認められな い。 


\section{2）第 1 次可溶性醋酸栈維素の溶解性 に對する考察}

\section{A）溶解度と沈澱方法との關俰}

かくの如く，普通の繊維素醋酸化條件の下に於て單に浴液を稀 䆁してフィルム狀に乾燥させると云ふ處理を加へたげけで優秀な 溶解性を有する醌酸䇅䊒素を製成し得たが，からる處理が果して 著者等が初めに考へた如く均一混合狀態の醋酸繊維素をつくるに 役立つザけけののか或は其他何何か重大な原因を包藏して居るも のかに就て先づ考察しよりと思ふっそのために先づ浴液を種々の 方法で沈澱せしめ生成した醌酸韯維素のアセトンに對する溶解度 を測定し、これより沈没方法が生成物の溶解度に如何なる影響を 與へるかを試驗した。郎ち未處理の風乾チ。シュ紙を第1 表の例 の浴 (無水醋酸 $40 \mathrm{cc}$, 醋酸 $40 \mathrm{cc}$, 硫酸 $\mathrm{Ig}$ ) で 4.5 時間醋酸化 た後その浴夜を次表に示す如き種々の方法に依つて沈澱せしめ， 共沈激物のアセトンに對する溶解度を測定したのでる。

\section{第 3 表}

醋酸化浴液の沈澱方法々生成醌酸繊維素の アセトンK對する溶解度との關保

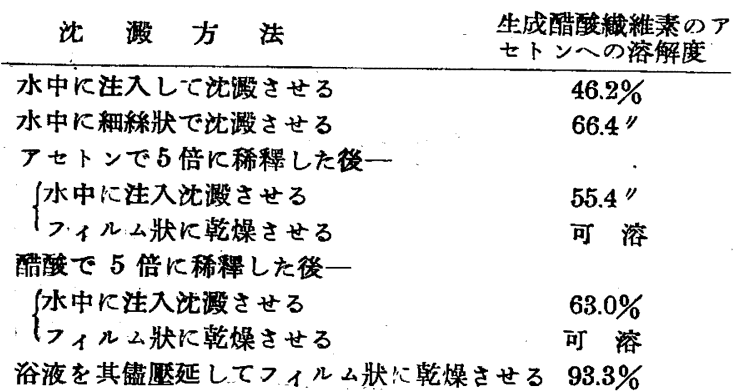

第 3 表を見るに，浴液を水中に注入して沈澱させた場合か㵊も 生成物の溶解度が小で僅か $462 \%$ に過ぎない。これ性，浴液が 非常に粘稠な餄狀の液體であるため全體の凝固が非常に縟徐に進 みその間に一種の分別沈溊の如き現象力起つて不均一混合物をつ くるためと思はれる, 從つて可及的急激に沈淑物をつくるため, 浴液を細流狀にして注入するときは得られた生成物の溶解度はか なり堵大して $66.4 \%$ を示す。次に浴液を广セトン或は醋酸で稀 釋してフィルム狀に乾燥すると何れるアセトンに透明可溶性の生 成物が得られるが,フィルム狀に乾燥寸る代りにこれを水中に注 入沈澱させるともはや可溶性物堀は得られず夫及 $55.4 \% ， 63 \%$ と云ふ小さい溶解度を示すにとがまる。これは稀䆁浴液を水中に 注入沈溊させる時, 全部の醌酸織維素が沈澱して來ないで一部の 可溶性部分は溶解したま」残る, 郎ちこの場合も一種の分別沈澱 が行はれて居るからである。からる可溶性部分は沈溊條件に休 り $10 \%$ から $20 \%$ に迋するが,か」る部分の微量の消失が溶 解度に如何に甚大な影響を與へるかは後の實駘にも明かに籍はれ る。最後に浴液を何等稀䆁せずそのま」出來るげけ墍延して厚さ $0.1 \mathrm{~mm} 以 下$ 程度の潧いフィルムとしこれに水或は醋酸りーダ水溶 液を流して固めたものに就て溶解度を調べた所，殆ど全部アセ卜 ンに溶解し, $93.3 \%$ の溶解度を示した。この場合浴液が湛げ粘稠 なため一樣に薄いフィルムをつくるのに竇驗上の困難があり，一 部分塊狀に固をつた所が不溶性となつたので，原則的には $100 \%$ 可溶性のものと考いられる。

かくの如くして著者等は，浴液を水中に注入沈激させた場合は

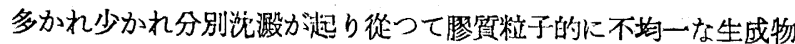
が得られるから不溶性となり，又フ、ルム狀に急速に固めると均 一な生成物が得られるから可溶性となると說明した。併しこのフ イルムにすると云ふ心㐆理が均一不均一と云ふ問題以外何か溶解 性汇重大な影響安與へるものかも知れないので，次に著者等は械 肘の第 2 次醋酸䋐維素セりっトを用ひ之をアセトンに溶解した後 フィルムとして再生した場合と水中注加して沈澱物として再生 した場合とに就き夫々のクロロフォルム及酷酸エチルへの溶解度 を測定し，溶解度が試料の再生方法に依てどんな影響を受げか を試驗したのである。

第 4 表は其實騟結果を示す。

第 4 表

セリットの溶解度と其再生方法との關倸

\begin{tabular}{|c|c|c|}
\hline & $\begin{array}{l}\text { クロロフォル } \\
\text { ムへの溶解度 }\end{array}$ & $\begin{array}{l}\text { 醌酸エチル } \\
\text { ○の溶解度 }\end{array}$ \\
\hline セリット原試料 & $5.95 \%$ & $24.9 \%$ \\
\hline 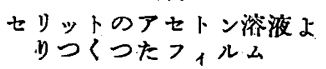 & $5.65 \prime \prime$ & $23.3^{\prime \prime}$ \\
\hline $\begin{array}{l}\text { セリットのアセトン溶液を } \\
\text { 水中に注入沈揤したもの }\end{array}$ & $5.12 "$ & $23.0 \prime$ \\
\hline
\end{tabular}

第 4 表に明かな如く單にフィルムにすると云ふ處理自身は溶 解度に大した影響を與へないことが制る。

\section{(B) 結合硫酸是の測定}

醌酸䋐維素の結合硫酸が其溶解度に撕から奴影響を及添すこと は從來屡々認められた所である (Deripasko, Zellulosechemie, 1931, 12,254 ; Caille, Chim. et Ind., 1931, 25, 276)。 そこで浴液 をフィルム狀に乾燥してつくつた七述の可溶性醋酸緎維素が普通 の方法でつくつた醋酸綫維素に比較して其結合硫酸量に著しい差 違があるか否かを確かめることにした，郎ち種々の沈澱方法に依 りつくつた醋酸䋐維素の溶解度々結合硫酸量の測定を行つた所， 次の第 5 表の如き結果を得た。但し結合硫酸量は常法の如く湘 定した，郎ち乾燥した科量試料的 $5 \mathrm{~g} に 35 \mathrm{cc}$ の濃盟酸を加へ 50 ${ }^{\circ} \mathrm{C}$ に溫めた後時々振蕰して完全に溶解させ，次に之に $6 \mathrm{cc}$ の浱

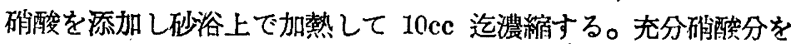
蒸發追放した後 $80 \mathrm{cc}$ の涨膫蒸溜水を加へ 15 分問沸䏲させる。 之を濾過した後常法の如く傿化バリウム溶液に依り硫酸分の定量 を行つたのである。

$$
\text { 第 } 5 \text {. 表 }
$$

同一の酛酸化浴加ら種々の沈澱方法に依り製成

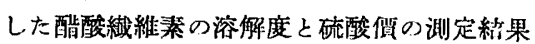

\begin{tabular}{|c|c|c|}
\hline 沈 澱 方 法 & $\begin{array}{l}\text { アセ卜溶 } \\
\text { 解度 }\end{array}$ & $\begin{array}{l}\text { 絠合硫酸 } \\
\text { 量 }(\%)\end{array}$ \\
\hline $\begin{array}{l}\text { 浴液を其侐水中に注入沈澱 } \\
\text { させる }\end{array}$ & 462 & 3.73 \\
\hline 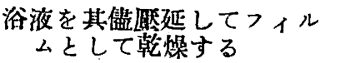 & 93.3 & 4.01 \\
\hline 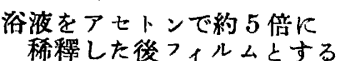 & 98.3 & 0.16 \\
\hline
\end{tabular}

第 5 表を見るに，醋酸化浴液を其睢水中に注入して沈澱させた 場合郎ち 通常の方法で 製成した醋酸瀻維素のアセトン溶解度は $46 \%$ に過ぎず結合硫酸量は $3.73 \%$ 白である。これに對し浴液をア セトンで稀釋してフィルムとして製成した醋酸䋐維素は大咀ア七 トンに可溶性であり結合硫酸量は $0.16 \%$ である。作しこれより 結合硫酸量の多少を以てアセ卜ン溶解度を云々することは出來な 
い，何故なら浴萑をそのま」呩延してフィルムとして製成した場 合, 結合研酸量は $4 \%$ 餘りもあるがアセトンに對する溶解度は 93.3\% ああるからである。これより考へて醋酸䋐維素の結合硫酸 量は溶解度に著しい影響を與へないととが判る。倫第 1 次醋酸䋐 維素は是を一旦溶剂中に溶解し後再生すると硫酸價が激減するこ とは (Deripasko 等 (交獻前出)の認めた所であり，浴液をアセ トンで稀䆁することに依り硫酸價の減少するのも類似の現象と考 へられる。

\section{(C) 均一混合性之溶解度}

上の如くして第 1 次可溶性醋酸䋘維素の 溶解性は沈激方法其 れ自身に体るものでもなく硫酸量の多家にも依るものでもない ことを明かにした。そこで最後にこの溶解性の原因は膠質粒子的 均一混合狀態にあることを明かにしようとするのである。即ち前 迅の如くにして製成された第1次可溶性醋酸䋐維素は，アセトン 可溶性の部分或はクロロフ*ルム可溶性の部分或は兩液體に可溶 性の部分等が適當に均一に混合して出來て居る。而して其可溶性 部分の溶解に伴つて不溶性の部分までが溶解を促進され遂に溶解 すると云ふ考へを確かめることにした。

そのために先づ，アセトンに良く溶解する部分を抽出除去して 其の殘りの部分が果してアセトンに非溶性になるかどらかを實驗 で確めることにした。アセトン可溶性の部分を除くと云つてもア セトン自身で處理すれば全體が溶解してしまうので次表の如くア

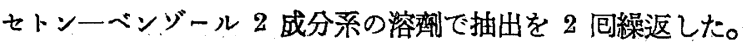

かくの如くして可及的にアセトン可溶性の部分を除去した殘り
第 1 次可溶性醋酸繊維素 $0.6152 \mathrm{~g}$

$$
\begin{aligned}
& \text { アセトン一ベンゾール(1:1)混合液體 } 40 \mathrm{cc} \text { で處理 } \\
& \text { 抽出部分 } 0.0500 \mathrm{~g} \text { 殘留部分 } 0.5652 \mathrm{~g} \\
& \text { アセトンーベンゾール(5:1)混合液體 } 60 \mathrm{ec} \text { で處理 } \\
& \text { 抽出部分 } 0.0490 \mathrm{~g}, \text { 残留部分 } 0.5162 \mathrm{~g}
\end{aligned}
$$

の部分（原試料に對し84\%) に關しアセトン及クロロフォルムに 對する浴解度を測定した所第 6 表の如き結果を得た。

$$
\begin{aligned}
& \text { 第 } 6 \text { 表 } \\
& \text { アセトン可溶性部分を可及的抽出除去した } \\
& \text { 第 } 1 \text { 次可溶性醋酸䋊維素の溶解度 } \\
& \begin{array}{ll}
\text { アセトンK数し } & 59.4 \% \\
\text { クロロフォルムに對し } & \text { 可 溶 }
\end{array}
\end{aligned}
$$

第6 表に見る如くアセトンに可溶性の部分を出來るだけ除去す るとアセトンに對する溶解度は激隇して僅か $59.4 \%$ になる, 一 カクロロフォルムに對する溶解度は何等影響を受けることなく依 然是に可溶性である。

以上の事筫より，例へばアセトン可溶性部分の混在が如何にア セトンへの溶解度に大きな役割を演じて居るか心゙明膫であり最初 に述へた著者等の溶解性に對する見解を主く裹書したのである。

倘製品の性質に關しては其〉ィルムの强伸度, 吸瀑度等を測定 したが何れもセリットより優れて居ることを認めた。是に關して は後報に詳細に述べることにする。

（京都帝國大學工學部工業化學教室·理化學研究所喜多研究窒）（昭和 13 年 1 月 20 日受理）

\title{
（45）セリットの稀薄溶液に關する嘱散實驗
}

\author{
谷口 政 勝 - 櫻 田一 郎
}

\section{要 旨}

セリットの水醋酸及アセトン溶液に關し其桸薄蜄度 $(0.5 \sim 0.6 \%)$

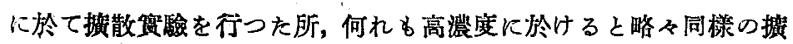

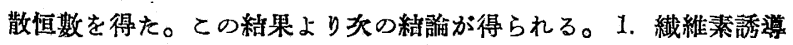
體の高分子物質の㑕散の際溶質粒子閒の相互作用が 常に閒題にな つて居るが, 潜透厥的或は粘度的に見て大體正常溶液々考一られる セリットの $0.5 \%$ 溶液の搬散璂驗絬果が高浱度溶液に於ける其れ之

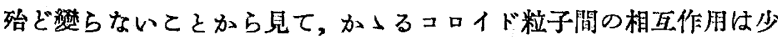
くとも控散現象の上に左程著しい影锌は與へないとと，2. Hess 等

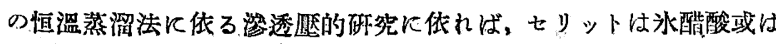
アセ卜ン溶液中に於て其溜度の減少と其飞階段的に解重合を起し 特に水醋酸溶液に於ては濃度, $0.5 \%$ ，附近飞至つて逐に $\left(\mathrm{C}_{6}\right)_{2}$ の狀 態火迄解重合すると述べて居るが，著者等つ上の粘果よりからる事 宽は全く認められぬとと。

偷本報告を以て「高分子物質並に其關保物質の攅散に依る政先」 の第 12 報とする。

$$
\text { 緒言 }
$$

繊維素誘道體等の如き高分子物質の撗散の際是了特徽ある異常 性が認められ，これに對し種々の原因が諸硎究者に依り考へられ
て居る。其の主なものを擧げれば第 1 に撗散物質の不均一性，第 2 に撗散粒子間の相互作用が考へられて居る。第 Iの原因に就て は既に著者等は本研究の第 5 報に於て理論的に是を究明し撗散物 質の不均一性に基く異常性は實歌誤差に比して餘り著しくないこ とを明かにした（本誌，昭和 $11 ， 39 ， 699 \% 。$

然るに第 2 の原因に關しては從來著者等は左程是を重大視せ ず, 嘪驗の容易な故を以て例へば醋酸繊維素に就ては $5 \%$ 內外の 高濃度溶液に關して擴散實驗を行つて來た。か〉る高濃度に於て は滲透䏩, 粘度等の物理化學的性質に明かに異常性が認められ溶 質粒子間の相互作用の影響は著しく現れて居る。そこでどらして も溶質粒子の相互作用の殆ど存在しないと考へられる稀薄正常溶 液に於て擴散璸驗を行ひ其結果を高濃度に於ける結果と比較檢討 して置く必要がある。本報告に於てはか」る見地から醋酸繊維素 の稀薄溶液に關する振散䆩臨を行はらとするのである。

\section{實驗結果及其考察}

擴散實驗方法は從來と全く同樣に Öholm 器を用ひ 4 㸴法或 は 3 厡法を用ひて行つた。醌酸纎維素としては市販のセりットを 用ひた，分散媒夜體としては醋酸及アセトンを用ひたが先つ醋酸 を分散媒に用ひた場合の結果に就て述べる。 